Home | Archives | About | Login | Submissions | Notify | Contact | Search

ES Home > Vol. 5, No. $2>$ Art. 1

Copyright @ 2001 by the author(s). Published here under license by The Resilience Alliance.

The following is the established format for referencing this article:

Gutman, M., I. Noy-Meir, D. Pluda, N. A. Seligman, S. Rothman, and M. Sternberg. 2001. Biomass

partitioning following defoliation of annual and perennial Mediterranean grasses. Conservation Ecology 5(2):

1. [online] URL: http://www.consecol.org/vol5/iss2/art1/

A version of this article in which text, figures, tables, and appendices are separate files may be found by following this link.

\title{
Report
}

\section{Biomass Partitioning Following Defoliation of Annual and Perennial Mediterranean Grasses}

Mario Gutman ${ }^{1}$, Imanuel Noy-Meir ${ }^{2}$, Daniel Pluda ${ }^{3}$, No'am Seligman $^{3}$, Steven Rothman ${ }^{3}$, and Marcelo Sternberg ${ }^{4}$

${ }^{1}$ Agricultural Research Organization; ${ }^{2}$ Hebrew University of J erusalem; ${ }^{3}$ Volcani Center; ${ }^{4}$ Bar-

I lan University

- Abstract

- Introduction

- Materials and Methods

- The grass species

- Planting and harvesting procedures

- Defoliation treatments

- Handling of the harvested biomass

- Field sampling

- Statistical analysis

- Results for Triticum dicoccoides

- Results for Hordeum bulbosum

- Discussion

- Responses of an annual and of a perennial grass

- Defoliation and tillering

- Management implications

- Responses to this Article

- Acknowledgments

- Literature Cited 
A two-year experiment was conducted in northeastern Israel to study the effects of various defoliation regimes on biomass partitioning between vegetative and reproductive structures in a perennial and an annual

Mediterranean grass. Greater insight into the mechanisms regulating biomass partitioning after defoliation enables ecologists and rangeland managers to interpret and predict population and community dynamics in Mediterranean grasslands more efficiently. Two typical Mediterranean grasses, Triticum dicoccoides, an annual species, and Hordeum bulbosum, a perennial species, were grown in containers in the open. They were subjected to a series of defoliation treatments that comprised three clipping frequencies and three clipping heights in a full factorial combination. In addition, individuals of both species were sampled in the field, in paddocks that were grazed, and in a control exclosure that was closed to grazing during the growing season. The experiment was conducted over two growing seasons, one unusually dry and one unusually wet. The clipping treatments invariably caused a reduction in the amount of biomass partitioned to the reproductive organs, but had little effect on the vegetative components of the plants. Greater tillering following

defoliation compensated, to a large degree, for the loss of photosynthetic biomass following defoliation. The effect of grazing on biomass partitioning was much lower than the effect of clipping. Under grazing, the investment in reproductive biomass was considerably higher than when the grasses were clipped. The results of this experiment help to elucidate the reasons for the persistence of these species and, especially, for the dominance of Hordeum bulbosum in many eastern Mediterranean grasslands.

KEY WORDS: annual vs. perennial grasses, biomass partitioning, defoliation treatments, grasslands, grazing response, Hordeum bulbosum, I srael, Mediterranean, reproductive effort, Triticum dicoccoides, vegetative vs. reproductive structures.

\section{NTRODUCTI ON}

Management of rangelands for both production and conservation of the flora requires information on the response of the principal plant species to key processes in the plant-herbivore system. An essential process in vegetation dynamics is biomass partitioning under grazing. This aspect of plant growth has been studied for many years in range pastures (Biswell and Weaver 1933) and in temperate pastures (Parsons and Robson 1981, Hunt et al. 1987), and models have been constructed based on accumulated knowledge (J ohnson and Thornley 1987, Spek and van Oijen 1988). The two dominant modes of biomass partitioning are between root and shoot and between vegetative and reproductive structures (Loehle 1987, Reekie and Bazzaz 1987, Horvitz and Schemske 1988). Grazing can influence both processes by affecting the demand for resources in either shoots or roots (sink strength) as well as the availability of meristems and their commitment to vegetative or

reproductive growth. Very little work has been done on the strongly seasonal Mediterranean grasslands (Ryle 1970).

Numerous biotic and abiotic factors influence partitioning between vegetative and reproductive plant organs. Grazing reduces the allocation to reproductive structures by removing rudimentary inflorescences or reducing photosynthetic surfaces and, consequently, the ability to photosynthesize (Hill and Watkin 1975, Caldwell et al. 1981, Butler and Briske 1988). On the other hand, grazing can increase the allocation to reproductive organs through its influence on tiller density and age-class distribution (Deregibus et al. 1985, Butler and Briske 1988, Noy-Meir and Briske 1996). Light grazing early in the season can increase the number of tillers that may potentially become reproductive later in the year (Knight 1970). However, severe grazing reduces the number of reproductive tillers.

Little work has been done on partitioning of biomass between vegetative and reproductive structures in annual grasses (de Ridder et al. 1981), and none of it has addressed the effects of defoliation and grazing.

This question is of special importance to species maintenance in the strongly seasonal Mediterranean grasslands (Noy-Meir and Briske 1996), where grazing may enhance the proportion of quality forage (leaves) by increasing the sink strength of shoots and limiting the number of reproductive tillers. However, the cost in reduced seed production or resource storage may have consequences for subsequent population dynamics and yield. Better information on the effects of defoliation and grazing on biomass partitioning in both annual and perennial grasses in the unique Mediterranean environment is needed to improve the forage quality and 
We report on experiments that were conducted to study the effects of various defoliation regimes on biomass partitioning between vegetative and reproductive structures in perennial (Hordeum bulbosum) and annual (Triticum dicoccoides) Mediterranean grasses. Defoliation frequency or intensity was varied to simulate a wide range of potential grazing situations and provide a basis for wider generalization at the process level. Although cutting experiments do not exactly simulate the natural grazing process, they provide an insight into the mechanisms regulating biomass partitioning after defoliation that enables ecologists and rangeland managers to interpret and predict population and community dynamics in Mediterranean grasslands more efficiently.

MATERI ALS AND METHODS

\section{The grass species}

Bulbous barley, Hordeum bulbosum L., is the most common perennial grass species in many eastern Mediterranean grasslands, with a wide distribution in both the Mediterranean and the Irano-

Turonian phytogeographical regions (Zohary 1989). It regenerates annually and reproduces asexually from corms ("bulbs") derived from thickened basal internodes at or just below the soil surface; it also produces abundant seeds. On many Mediterranean grasslands it is a major dominant under a wide range of grazing intensities (Seligman 1996, Sternberg et al. 2000). Wild emmer wheat, Triticum dicoccoides (Koern.) Aarons., is a tall, large-seeded annual grass commonly found in eastern Galilee and on the Golan Heights, especially on basaltic soils. It is sometimes locally dominant in lightly grazed areas or ungrazed sites (Noy-Meir et al. 1989). It can be regarded as representative of the tall Mediterranean annual grasses that include wild oat, Avena sterilis L., and annual wild barley, Hordeum spontaneum C. Koch.

\section{Planting and harvesting procedures}

Experiments were conducted in the growing seasons of 1991-1992 and 1992-1993 from the beginning of the rainy season in autumn (November) to the beginning of the dry season in early summer (May). Wild emmer wheat seeds were harvested from plants raised in a field nursery from seeds collected from local populations at the Karei Deshe Experimental Station in northeastern Galilee, just north of the Sea of Galilee in Israel (Gutman et al. 1990). Bulbous barley corms were collected in Karei Deshe prior to the experiment. In the first year, the plants were grown in $50-\mathrm{L}$ plastic containers, $40 \mathrm{~cm}$ in diameter and $40 \mathrm{~cm}$ deep, that were filled with local topsoil (basaltic protogrumosol). In the second year, the soil was mixed with pumice (2:1 v/v topsoil: pumice) to improve aeration and to prevent cracking of the heavy soil.

Each container was sown with 30 wheat seeds in an unheated shadehouse at the beginning of November before the first rainfall. After germination, the seedlings were thinned to 15 per container and positioned in two concentric circles, with 11 plants in the outer circle and four in the inner circle and a distance of approximately 5 $\mathrm{cm}$ between plants. In the second year, this procedure was repeated. In the first year, $\mathrm{H}$. bulbosum corms were also planted in November, but after the first rain. Because of unusually high temperatures at the time, many of the corms dried out and were replaced with fresh corms. This caused great survival variability among the plants in the containers. In some containers, 15 plants survived; in others, only 8-14. In the second year, 15 middlesized corms that appeared to be viable were planted in each container. Some sprouted immediately, others delayed sprouting until 10 days after planting, and some dried out and failed to sprout. The final number of plants per container varied from seven to 15 .

In the first year, which was unusually dry, the containers were irrigated to prevent the soil from drying out. They were irrigated six times between rainfall events, each time with an amount equivalent to $15-20 \mathrm{~mm}$ rainfall (Table 1$)$. In the second year, the winter was unusually wet, but the spring was relatively dry. The containers were irrigated once soon after planting and seven times in the spring, also with an amount equivalent to 5-20 mm rainfall each time (Table 1 ). In the second year, plants were fertilized once in December with $1.5 \mathrm{~g}$ urea per container (equivalent to $70 \mathrm{~kg} \mathrm{~N} / \mathrm{ha}$ ) to make up for probable nitrogen deficiency in the soil, which had been leached by abundant winter rains. Because the weather during January and February was also extremely 
Table 1. Rainfall $(\mathrm{mm})$ and irrigation $(\mathrm{mm})$ of the containers of Triticum dicoccoides and Hordeum bulbosum during the experiment.

\begin{tabular}{|c|c|c|c|c|}
\hline & \multicolumn{2}{|c|}{ 1990-1991 } & \multicolumn{2}{|c|}{ 1991-1992 } \\
\hline Month & Rainfall & Irrigation & Rainfall & Irrigation \\
\hline October & 13 & 0 & 0 & 0 \\
\hline November & 13 & 30 & 104 & 5 \\
\hline December & 37 & 30 & 361 & 0 \\
\hline January & 128 & 15 & 224 & 0 \\
\hline February & 57 & 0 & 295 & 0 \\
\hline March & 78 & 0 & 29 & 20 \\
\hline April & 37 & 20 & 0 & 70 \\
\hline
\end{tabular}

\section{Defoliation treatments}

In each year, both species were subjected to defoliation at three frequencies and three clipping heights in a fully factorial combination. In addition, there was one unclipped control, giving a total of 10 treatments (Table

2). Defoliation dates were set according to the development of the phenological phases: early vegetative,

late vegetative, and early reproductive. Clipping heights represented mild, moderate, and heavy defoliation.

The series of defoliation treatments began about 10 weeks after planting.

Table 2. Clipping heights and harvest schedules.

\begin{tabular}{|c|c|c|c|c|c|c|c|c|c|c|}
\hline \multirow{2}{*}{ Parameter } & \multicolumn{10}{|c|}{ Treatment no. } \\
\hline & 1 & 2 & 3 & 4 & 5 & 6 & 7 & 8 & 9 & 10 \\
\hline \multicolumn{11}{|l|}{ First year, 1990-1991 } \\
\hline Clipping height $(\mathrm{cm})$ & 1 & 2.5 & 5 & 1 & 2.5 & 5 & 1 & 2.5 & 5 & Control \\
\hline \multicolumn{11}{|l|}{ Clipping date } \\
\hline 6-8 Feb & - & - & - & - & - & - & + & + & + & - \\
\hline 4-7 Mar & - & - & - & + & + & + & + & + & + & - \\
\hline 21-27 Mar & + & + & + & + & + & + & + & + & + & - \\
\hline 17 Apr-9 May & + & + & + & + & + & + & + & + & + & + \\
\hline \multicolumn{11}{|l|}{ Second year, 1991-1992 } \\
\hline Residual fraction & 0.125 & 0.250 & 0.500 & 0.125 & 0.250 & 0.500 & 0.125 & 0.250 & 0.500 & Control \\
\hline \multicolumn{11}{|l|}{ Clipping date } \\
\hline 22-29 Jan & + & + & + & + & + & + & + & + & + & - \\
\hline
\end{tabular}




\begin{tabular}{|c|c|c|c|c|c|c|c|c|c|c|}
\hline 4-9 Mar & - & - & - & + & + & + & + & + & + & - \\
\hline 29 Apr-5 Mar & - & - & - & - & - & - & + & + & + & - \\
\hline 28 Apr-10 May & + & + & + & + & + & + & + & + & + & - \\
\hline
\end{tabular}

Note: Triticum dicoccoides was clipped on the first date in each range, Hordeum bulbosum on the second. The minus sign (-) stands for "not havested," the plus sign (+) for "harvested." The last harvest was at the end of the growing season on the final date given, which varied among treatments. At that time, aboveground biomass in all containers, including the control, was clipped at ground level. Corms of H. bulbosum were harvested separately.

In the first year, clipping height was fixed at three levels above ground. In the second year, clipping height was determined as a fraction of plant height in each container.

Treatments were randomized in 10 replicated blocks for each species. Clipping schedules differed between the two years so as to provide a wider range of defoliation scenarios. In the first year, clipping heights were fixed at $1.0,2.5$, and $5.0 \mathrm{~cm}$ above the ground, regardless of the height of the plant. In the second year, clipping heights were set proportional to the heights of the plants: $0.125,0.25$, and 0.5 of sward height. This approach simulated the finding that cattle tend to graze a proportion of the sward height rather than down to a fixed residual height (Laca et al. 1992). Furthermore, in the first year, one-third of the treatments were clipped at the first defoliation, two-thirds at the second, and all at the third. In the second year, the order was reversed: all treatments were clipped at the first defoliation, two-thirds at the second defoliation, and one-third at the third defoliation. Thus, in the first year, treatments that were defoliated once grew undisturbed for most of the season and were not defoliated until the beginning of the reproductive phase; in the second year,

treatments defoliated once were defoliated early in the vegetative phase and recovered during the rest of the growing season. At the end of the growing season, as the plants began to dry out, the aboveground biomass in the control and in all the treatment containers was clipped at ground level. The corms of $\mathrm{H}$. bulbosum were dug out of the ground after the last harvest and cleaned of soil. The detailed treatment schedule is given in Table 2 .

\section{Handling of the harvested biomass}

The aboveground harvested material from each container at each clipping was separated into spikes, leaves, and tillers. In each year, corms were dug out at the final harvest at the end of the season. The separated material was dried at $65^{\circ} \mathrm{C}$ for $48 \mathrm{~h}$ and weighed to $0.1-\mathrm{g}$ precision.

\section{Field sampling}

Plants of $\mathrm{T}$. dicoccoides and $\mathrm{H}$. bulbosum were sampled regularly in an ungrazed control plot and in experimental plots at Karei Deshe that were subjected to stocking rates of 0.83 and 0.5 cows per ha. The grazing experiment comprised two blocks (two replicates/paddocks per treatment). The control exclosures were protected from grazing during the growing season but open to grazing during the dry summer. In the first year, 20 plants of $\mathrm{H}$. bulbosum and 25 plants of $\mathrm{T}$. dicoccoides were randomly sampled in each of the six paddocks; in the second year, the sampling size was increased to 35 plants of each species. All samples were collected within a permanent $30 \times 30$ m area. Growth parameters were estimated, and the plant material was separated into vegetative and reproductive components, dried for $48 \mathrm{~h}$ at $65^{\circ} \mathrm{C}$, and weighed.

\section{Statistical analysis}

The size and significance of the treatment effects were analyzed with the GLM procedure developed by the SAS Institute (1985). The model included clipping height, clipping frequency, and year as well as the interactions between them. Individual plants sampled in the field were regarded as individual observations and served as replicates in a one-way ANOVA. The means of the significant differences were separated using the Tukey hsd (honestly significant difference) test $(P<0.05)$. 


\section{RESULTS FOR TRITI CUM DI COCCOI DES}

Except for the reproductive fraction and the number of tillers, interactions between the effects of defoliation frequency and clipping height were not significant. Consequently, in most cases, these effects can be viewed independently of each other.

\section{Accumulated end-of-season total biomass}

In both years, the accumulated end-of-season total biomass of all clipping treatments was substantially lower than the mean end-of-season biomass in the control (Tables 3 and $\underline{4}$ ) and decreased with increasing

clipping frequency. In the first year, the effect of constant clipping heights on total biomass was not significant. In the second year, the more severe relative clipping heights $(0.125,0.25)$ reduced total yield, whereas the light clipping height $(0.5)$ had only a small effect. Biomass yields were higher in the second year. This was most likely a result of the drier conditions in the first year despite irrigation (Table 1), combined with the fact that nitrogen fertilizer was added to the containers in the second year.

Table 3. Reproductive fractions of Triticum dicoccoides: first year.

\begin{tabular}{|c|c|c|c|c|c|c|c|c|c|c|}
\hline \multirow[t]{2}{*}{ Component } & \multirow[t]{2}{*}{ Control } & \multicolumn{4}{|c|}{$\begin{array}{l}\text { Clipping frequency } \\
\text { (no. times clipped) }\end{array}$} & \multicolumn{4}{|c|}{$\begin{array}{l}\text { Clipping height } \\
(\mathrm{cm})\end{array}$} & \multirow{2}{*}{\begin{tabular}{|c} 
Interaction \\
$\begin{array}{c}\text { Fraction } \\
\text { x height }\end{array}$ \\
\end{tabular}} \\
\hline & & 1 & 2 & 3 & Significance & 5 & 2.5 & 1 & Significance & \\
\hline Total shoot biomass $(\mathrm{g} D M)^{\S}$ & $74 * *$ & $57 a$ & $50^{\mathrm{b}}$ & $46^{b}$ & $* *$ & 54 & 49 & 50 & NS & NS \\
\hline Vegetative biomass (g DM) & 49 NS & $49 a$ & $44 \mathrm{ab}$ & $40^{\mathrm{b}}$ & $* *$ & 45 & 43 & 45 & NS & NS \\
\hline $\begin{array}{l}\text { Reproductive biomass, spikes } \\
\text { (g DM) }\end{array}$ & $25^{* * *}$ & $8^{a}$ & $6^{a}$ & $7^{b}$ & $*$ & $9^{a}$ & $6 \mathrm{~b}$ & $5^{b}$ & $* * *$ & NS \\
\hline Reproductive plants (\%) & $34 * * *$ & 14 & 12 & 14 & NS & $17^{a}$ & $12^{b}$ & $10^{b}$ & $* * *$ & NS \\
\hline No. tillers/plant (2 April) & $4.3 * * *$ & $4.8^{b}$ & $7.5^{a}$ & $7.7^{a}$ & ** & $5.8^{b}$ & $7.0^{a}$ & $7.2^{\mathrm{a}}$ & ** & * \\
\hline
\end{tabular}

Significance of the difference between the control and the mean of all the defoliation treatments.

$* \mathrm{P}<0.05 ; * * \mathrm{P}<0.01 ; * * * \mathrm{P}<0.001$; NS, nonsignificant.

Difference between the control and mean of all defoliation treatments.

In the first year, one-third of the treatments were clipped at the first defoliation, two-thirds at the second, and all at the third. Values followed by different letters are significantly different.

$\S$ Values given represent grams of dry matter per container with a soil surface area of $1.25 \mathrm{~m}^{2}$. 
Table 4. Effect of defoliation treatments on partitioning of the vegetative and reproductive fractions of Triticum dicoccoides: second year.

\begin{tabular}{|c|c|c|c|c|c|c|c|c|c|c|}
\hline \multirow[t]{2}{*}{ Component } & \multirow[t]{2}{*}{ Control } & \multicolumn{4}{|c|}{$\begin{array}{l}\text { Clipping frequency } \\
\text { (no. times clipped) }\end{array}$} & \multicolumn{4}{|c|}{ Residual fraction } & \multirow{2}{*}{\begin{tabular}{|c} 
Interaction \\
$\begin{array}{c}\text { Fraction } x \\
\text { height }\end{array}$
\end{tabular}} \\
\hline & & 1 & 2 & 3 & Significance & 0.5 & 0.25 & 0.125 & Significance & \\
\hline Total shoot biomass (g DM)§ & $111 * * *$ & $99 a$ & $87^{b}$ & $85^{b}$ & $* * *$ & $103^{a}$ & $84^{b}$ & $83^{b}$ & $* * *$ & NS \\
\hline Vegetative biomass (g DM) & $85 * * *$ & 75 & 70 & 75 & NS & $81^{a}$ & $70^{b}$ & $70^{b}$ & $*$ & NS \\
\hline $\begin{array}{l}\text { Reproductive biomass, spikes } \\
\text { (g DM) }\end{array}$ & $25^{* * *}$ & $24^{a}$ & $16^{b}$ & 9c & $* * *$ & $22^{a}$ & $14^{b}$ & $13^{b}$ & $* * *$ & NS \\
\hline Reproductive plants (\%) & $23 * * *$ & $24^{a}$ & $19 \mathrm{~b}$ & $12^{\mathrm{c}}$ & $* * *$ & $22^{a}$ & $17^{b}$ & $16^{b}$ & $* * *$ & $* *$ \\
\hline No. tillers/plant (15 April) & $2.5 * * *$ & 2.5 & 4.5 & 4.8 & NS & $3.1^{\mathrm{a}}$ & $4.8^{b}$ & $5.8^{\mathrm{C}}$ & $* * *$ & $* * *$ \\
\hline
\end{tabular}

$* \mathrm{P}<0.05 ; * * \mathrm{P}<0.01 ; * * * \mathrm{P}<0.001 ; \mathrm{NS}$, nonsignificant.

Difference between the control and the mean of all the defoliation treatments.

In the second year, all treatments were clipped at the first defoliation, two-thirds at the second

defoliation, and one-third at the third defoliation. Values followed by different letters are

significantly different.

$\S$ Values given represent grams of dry matter per container with a soil surface area of $1.25 \mathrm{~m}^{2}$.

\section{Vegetative biomass}

In the first year, defoliation treatments did not have a significant effect on accumulated vegetative biomass. In the second year, the effect was significant but considerably less than that on total biomass. Increased clipping frequency slightly decreased accumulated vegetative yield in the first year but had an ambiguous effect in the second year. On the other hand, the effect of clipping height was not significant in the first year. In the second year, the more severe defoliation reduced vegetative biomass significantly, although the yield of the light clipping treatment (0.5) was not much lower than that of the control.

\section{Reproductive biomass}

In contrast to vegetative biomass, the effects of defoliation treatments on reproductive (spike) biomass were highly significant (Tables 3 and 4). In the first year, the effects of clipping treatments were much more drastic than in the second year, possibly because of the more severe range of clipping heights. On average, clipping reduced spike biomass to less than one-third of that of the control; in the second year, average spike biomass on the clipped plants was two-thirds that of the control plants. The effects of clipping frequency and clipping height were significant in both years. In the first year, when all treatments were clipped at the third clipping date in the reproductive stage, the overall effect of clipping was large, but the differences among clipping treatments were small. In the second year, when all treatments were clipped early in the vegetative stage, there were large differences among them. Spike mass on the plants that were clipped only once (early) or at the light clipping height (0.5) was not significantly less than that of the control plants, but was significantly greater than that in the treatments that involved severe clipping in the reproductive stage.

\section{The reproductive fraction}


The effect of defoliation treatments on this variable (spikes per total biomass) was very similar to their effect on spike mass.

\section{Tillers per plant}

In both years, the overall effect was the same: increased clipping frequency and more severe clipping heights increased tillering. In the second year, however, the frequency effect was not significant. On the other hand, the interaction (frequency $x$ height) was highly significant: at the most severe defoliation (0.125), tiller numbers were significantly higher in both the two- and three-clipping treatments, whereas, at the more lenient defoliation, tiller numbers were significantly higher only with three clippings.

\section{The reproductive fraction in grazed plants}

At the April sampling, the plants in both grazed paddocks were grazed down to about half the size of the plants in the control. In both 1991 and 1992, the reproductive fraction of T. dicoccoides plants was higher in the ungrazed control than in the grazed paddocks (Table 5). This is similar to the effect of clipping on the

reproductive fraction of $\mathrm{T}$. dicoccoides, except that the effect of grazing was not as severe as that of the clipping treatments. Differences between the two grazing intensities were not significant.

Table 5. Biomass partitioning in Triticum dicoccoides and Hordeum bulbosum plants taken at the end of the growing season in 1991 and 1992 from grazed paddocks at different stocking rates: $\mathrm{H}$ (heavy),

0.83 cows/ha; $M$ (moderate), 0.5 cows/ha; and C (control), ungrazed.

\begin{tabular}{|c|c|c|c|c|c|c|c|c|c|c|c|c|}
\hline \multirow[t]{3}{*}{ Biomass components } & \multicolumn{6}{|c|}{ Triticum dicoccoides } & \multicolumn{6}{|c|}{ Hordeum bulbosum } \\
\hline & \multicolumn{3}{|c|}{21 April 1991} & \multicolumn{3}{|c|}{13 April 1992} & \multicolumn{3}{|c|}{22 April 1991} & \multicolumn{3}{|c|}{20 April 1992} \\
\hline & $\mathrm{H}$ & M & C & $\mathrm{H}$ & M & C & $\mathrm{H}$ & M & C & $\mathrm{H}$ & M & C \\
\hline $\begin{array}{l}\text { Total biomass } \\
\text { ( } \mathrm{g} / \text { plant) }\end{array}$ & 3.6 & 2.9 & 4.0 & $1.0^{\mathrm{b}}$ & $1.2^{\mathrm{b}}$ & $2.8^{a}$ & $2.3^{b}$ & $2.3^{b}$ & $5.2^{a}$ & $4.2^{b}$ & $5.3^{b}$ & $7.7^{a}$ \\
\hline Reproductive fraction & $0.39^{b}$ & $0.40^{b}$ & $0.47 a$ & $0.68^{b}$ & $0.70^{b}$ & $0.76^{a}$ & $0.45^{a}$ & $0.44^{a}$ & $0.35^{b}$ & $0.41^{a}$ & $0.39 a$ & $0.34^{b}$ \\
\hline Corm fraction $\S$ & $\ldots$ & $\ldots$ & $\ldots$ & $\ldots$ & $\ldots$ & $\ldots$ & 0.84 & 0.86 & 0.71 & 0.75 & 0.72 & 0.68 \\
\hline
\end{tabular}

The means of the significant differences were separated using the Tukey hsd (honestly significant difference) test $(P<0.05)$ from the SAS Institute (1985). Nonsignficant (or derived) differences have been left unmarked. Values followed by different letters are significantly different.

Reproductive fraction is spikes/total biomass for $\mathrm{T}$. dicoccoides and (spikes + corms)/total biomass for H. bulbosum.

$\S$ Corm fraction is corms/(spikes + corms)

\section{RESULTS FOR HORDEUM BULBOSUM}

\section{Accumulated end-of-season total biomass}

In both years, as in the case of Triticum dicoccoides, accumulated end-of-season total biomass in all clipping treatments was significantly lower than that of the control (Tables 6 and $\underline{7}$ ). The depressive effect on

http://www.ecologyandsociety.org/vol5/iss2/art1/ (8 of 17) [10/20/2008 3:19:28 PM] 
Table 6. Effect of defoliation treatments on partitioning of the vegetative and reproductive fractions of Hordeum bulbosum: first year.

\begin{tabular}{|c|c|c|c|c|c|c|c|c|c|c|}
\hline \multirow[t]{2}{*}{ Component } & \multirow[t]{2}{*}{ Control } & \multicolumn{4}{|c|}{$\begin{array}{l}\text { Clipping frequency } \\
\text { (no. times clipped) }\end{array}$} & \multicolumn{4}{|c|}{ Clipping height $(\mathrm{cm})$} & \multirow{2}{*}{\begin{tabular}{|c|} 
Interaction \\
$\begin{array}{c}\text { Fraction } x \\
\text { height }\end{array}$
\end{tabular}} \\
\hline & & 1 & 2 & 3 & Significance & 5 & 2.5 & 1 & Significance & \\
\hline $\begin{array}{l}\text { Total shoot biomass } \\
(\mathrm{g} D \mathrm{DM})^{\S}\end{array}$ & $120 * * *$ & $103^{a}$ & $93^{b}$ & $84^{c}$ & $* * *$ & $99^{a}$ & $92^{b}$ & $92^{b}$ & $*$ & NS \\
\hline $\begin{array}{l}\text { Vegetative biomass } \\
\text { (g DM) }\end{array}$ & 64NS & $56^{a}$ & $55^{a}$ & $50^{a b}$ & NS & 54 & 54 & 53 & NS & NS \\
\hline $\begin{array}{l}\text { Spikes } \\
\text { (g DM) }\end{array}$ & $7 * * *$ & 4 & 2 & 2 & NS & 3 & 2 & 2 & NS & NS \\
\hline $\begin{array}{l}\text { Corms } \\
\text { (g DM) }\end{array}$ & $49 * * *$ & $43^{a}$ & $36^{b}$ & $32^{b}$ & $* * *$ & $42^{a}$ & $35^{b}$ & $32^{b}$ & $* * *$ & NS \\
\hline Reproductive fraction (\%)| & $47 * * *$ & $45^{a}$ & $41^{b}$ & $41^{c}$ & $* *$ & $46^{a}$ & $41^{b}$ & $40^{b}$ & $* *$ & NS \\
\hline $\begin{array}{l}\text { No. tillers/plant } \\
\text { (4 April) }\end{array}$ & $11.5 * * *$ & $8.3^{a}$ & $12.9^{b}$ & $17.5^{c}$ & $* * *$ & $16.8^{b}$ & $11.3^{a}$ & $10.3^{a}$ & $* *$ & NS \\
\hline
\end{tabular}

$* \mathrm{P}<0.05 ; * * \mathrm{P}<0.01 ; * * * \mathrm{P}<0.001 ; \mathrm{NS}$, nonsignificant.

Difference between the control and the mean of all the defoliation treatments.

In the first year, one-third of the treatments were clipped at the first defoliation, two-thirds at the second, and all at the third. Values followed by different letters are significantly different.

$\S$ Values given represent grams of dry matter per container with a soil surface area of $1.25 \mathrm{~m}^{2}$.

IReproductive fraction is spikes + corms.

Table 7. Effect of defoliation treatments on partitioning of the vegetative and reproductive fractions of Hordeum bulbosum: second year.

\begin{tabular}{|c|c|c|c|c|c|c|c|c|c|c|}
\hline \multirow[t]{2}{*}{ Component } & \multirow[t]{2}{*}{ Control } & \multicolumn{4}{|c|}{$\begin{array}{l}\text { Clipping frequency } \\
\text { (no. times clipped) }\end{array}$} & \multicolumn{4}{|c|}{ Residual fraction } & \multirow{2}{*}{\begin{tabular}{|c|} 
Interaction \\
$\begin{array}{c}\text { Fraction } \mathrm{x} \\
\text { height }\end{array}$
\end{tabular}} \\
\hline & & 1 & 2 & 3 & Significance & 0.5 & 0.25 & 0.125 & Significance & \\
\hline $\begin{array}{l}\text { Total shoot biomass } \\
(\mathrm{g} \text { DM })^{\S}\end{array}$ & 140 & $130^{a}$ & $122^{b}$ & $115^{c}$ & $* * *$ & $136^{a}$ & $116^{b}$ & $116^{b}$ & $* * *$ & NS \\
\hline $\begin{array}{l}\text { Vegetative biomass } \\
\text { (g DM) }\end{array}$ & $78^{* *}$ & $74^{a}$ & $73^{a}$ & $68^{b}$ & $*$ & $76^{a}$ & $67 \mathrm{~b}$ & $71^{\mathrm{ab}}$ & $*$ & NS \\
\hline
\end{tabular}


Conservation Ecology: Biomass partitioning following defoliation of annual and perennial Mediterranean grasses

\begin{tabular}{|c|c|c|c|c|c|c|c|c|c|c|}
\hline $\begin{array}{l}\text { Spikes } \\
\text { (g DM) }\end{array}$ & $7 * * *$ & $7 \mathrm{~b}$ & $8^{a}$ & $3 c$ & $* * *$ & 6 & 6 & 6 & NS & NS \\
\hline $\begin{array}{l}\text { Corms } \\
\text { (g DM) }\end{array}$ & $55^{* * *}$ & $48^{a}$ & $41^{c}$ & $46^{b}$ & $* * *$ & $53^{a}$ & $42^{b}$ & $38^{c}$ & $*$ & $*$ \\
\hline Reproductive fraction (\%)| & $45 *$ & 43 & 40 & 41 & NS & $44^{a}$ & $42^{\mathrm{ab}}$ & $38^{b}$ & $*$ & $*$ \\
\hline $\begin{array}{l}\text { No. tillers/plant } \\
\text { (17 April) }\end{array}$ & $5.3^{* * *}$ & $7.2^{a}$ & $9.7^{b}$ & $13.1^{\mathrm{c}}$ & $* * *$ & $8.7^{b}$ & $10.8^{a}$ & $10.5^{a}$ & $*$ & $*$ \\
\hline
\end{tabular}

$* \mathrm{P}<0.05 ; * * \mathrm{P}<0.01 ; * * * \mathrm{P}<0.001 ; \mathrm{NS}$, nonsignificant.

Difference between the control and the mean of all the defoliation treatments.

In the second year, all treatments were clipped at the first defoliation, two-thirds at the second

defoliation, and one-third at the third defoliation. Values followed by different letters are

significantly different.

$\S$ Values given represent grams of dry matter per container with a soil surface area of $1.25 \mathrm{~m}^{2}$. I

Reproductive fraction is spikes + corms.

\section{Vegetative biomass}

In the first year, defoliation treatments did not have a significant effect on accumulated vegetative biomass, whereas, in the second year, there was a small but significant negative effect. Differences among the effects of clipping severity were smaller than in the case of T. dicoccoides, especially in the second year.

\section{Reproductive biomass}

Corms constitute the bulk of the reproductive biomass in $\mathrm{H}$. bulbosum. Even in the control plants, spike mass was only about one-third that of T. dicoccoides. The effect of clipping frequency was significant only in the second year, and clipping height was not significant in either year. On the other hand, corm mass was significantly reduced by both frequency of defoliation and severity of clipping height, although the reduction never exceeded $20 \%$ of the corm mass in control plants.

\section{The reproductive fraction}

The effects of defoliation treatments on the reproductive fraction (spikes + corms) were similar to their effects on corm mass, except that, on the whole, the effects were much smaller. The effects of clipping treatment were almost identical in both years.

\section{Tillers per plant}

Tiller numbers changed considerably during the season (Fig. 1), so that the numbers at any one point in time were not very meaningful. Nevertheless, toward the end of the growing season, increased clipping

frequency increased tiller numbers per plant, whereas the effect of clipping height was ambiguous. 
Fig. 1. Changes in tiller number per plant in the control treatment (not clipped) of the container trial during two growing seasons. Hb stands for Hordeum bulbosum, Td for Triticum dicoccoides.
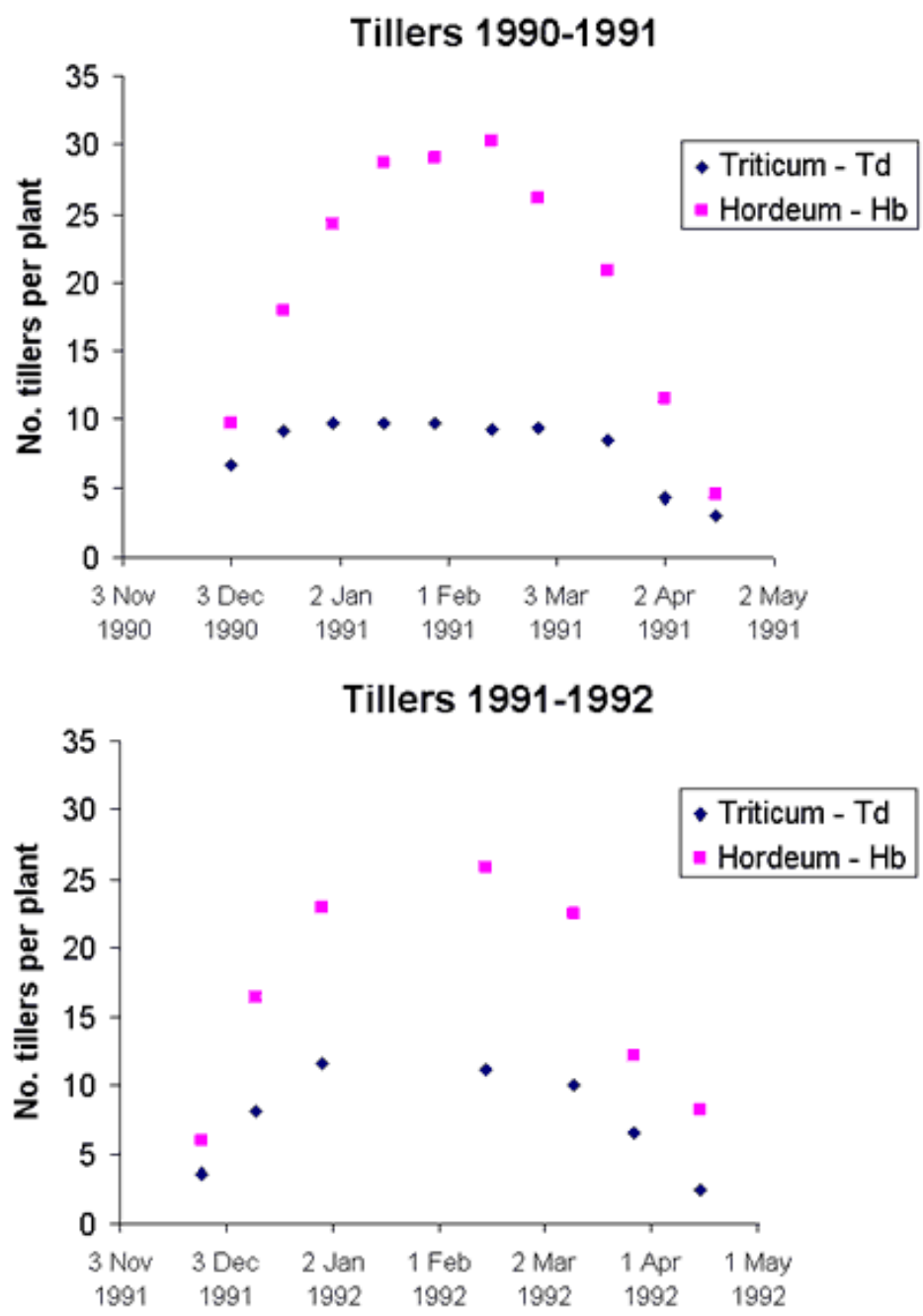

\section{The reproductive fraction in grazed plants}

In the control paddock, the fraction of reproductive organs in the field was smaller than in either grazed

paddock ( $\underline{\text { Table 5 }}$ ). However, this was a consequence of the defoliation caused by grazing: the actual mass of

corms as well as the number of corms per plant were consistently (and generally significantly) higher in the

control paddock (Fig. 2). 
Fig. 2. Effect of grazing on the change in the number of new corms per culm of $\mathrm{H}$. bulbosum in the spring of 1991 and the spring of 1992. C stands for the control paddock without grazing, M for paddocks grazed at moderate stocking rates, and $\mathrm{H}$ for paddocks grazed at heavy stocking rates.
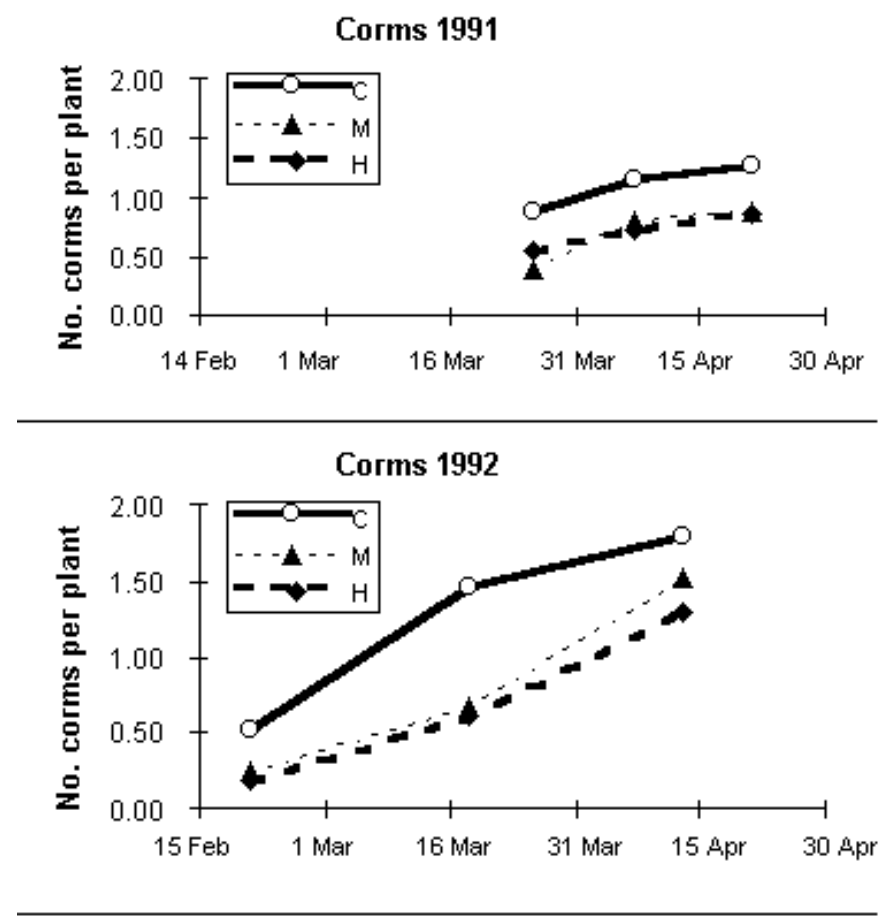

\section{DISCUSSION}

\section{Responses of an annual and of a perennial grass}

The life-forms of Hordeum bulbosum and Triticum dicoccoides are different: one is a perennial hemicryptophyte, and the other is an annual therophyte (Raunkaier 1934, Orshan 1953). Nevertheless, their annual life cycles are dominated by the strongly seasonal Mediterranean climate, with the result that their phenologies are closely synchronized. That is possibly the reason for their similar response to defoliation at any time during the growing season (Noy-Meir 1978). However, their partitioning priorities are quite different: T. dicoccoides can invest only in the spike, whereas $\mathrm{H}$. bulbosum must divide its reproductive biomass between the spike and the asexual corms. In addition, H. bulbosum clearly favors the corms, regardless of whether the plant is defoliated during its growth. Exploiting such an option for perennial growth can be advantageous only if the species can withstand grazing as well as a long, dry, hot summer. Indeed, even though the biomass and number of the corms are reduced by grazing (Tables 6 and 7, Fig. 2), the effect is less severe than the effect on the spikes. $\mathrm{H}$. bulbosum also demonstrates plasticity by becoming more prostrate under heavy grazing. In addition, the tillers that arise from buds below the corms (Ofir et al. 1967) are initially protected by the overlying corm. 
Tiller numbers per plant were high compared with T. dicoccoides, a property that facilitates tolerance of grazing (Fig. 1). In the spring, the number of new corms grows rapidly (Fig. 2), and soon afterwards they become dormant as the plant dries up at the beginning of the summer. Even though reproductive spikes form only a small part of the investment in reproductive biomass, there is still a substantial investment in seed (Koller and Highkin 1960). The wide distribution and dominance of $\mathrm{H}$. bulbosum in eastern Mediterranean grasslands is an indication of the success of the partitioning strategy of the species (Seligman 1996).

Despite the fact that $\mathrm{T}$. dicoccoides can opt only for sexual reproduction, it invests less in reproductive biomass than does $\mathrm{H}$. bulbosum. Seed composition and the accompanying defense and distribution mechanisms are evidently more demanding on assimilates than are vegetative corm structures (Ryle 1970). Although seed production in $\mathrm{T}$. dicoccoides is sensitive to severe defoliation (Table 3 ), in the field the plant maintains an impressive investment in reproductive biomass, similar to, and even greater than, that of $\mathrm{H}$. bulbosum. This finding suggests that the highly uneven nature of grazing may be less severe than the lightest defoliation treatments that were applied in this experiment.

\section{Defoliation and tillering}

Tillering in grasses is a very dynamic process, and time of sampling can strongly influence the situation encountered (Fig. 2). Repeated defoliation tended to increase tiller number but reduce the number of spikes. Stimulation of tillering by clipping may result from the removal of apical dominance (Leopold 1949, Carman and Briske 1982, Butler and Briske 1988) or from increased intensity and quality of radiation (red light) at ground level (Deregibus et al. 1985, Kasperbauer and Karlen 1986). Most of the additional tillers remained vegetative, and the effect of defoliation on vegetative biomass was generally insignificant or very low. Tiller number tended to increase at lower clipping heights, except in the case of $\mathrm{H}$. bulbosum in the first year.

\section{Management implications}

The response of the two different but representative grasses studied in this experiment suggests that they can be grazed quite intensively with little loss of accumulated vegetative biomass. The depressive effect of defoliation on the reproductive component of the biomass was substantial and highly significant, especially after severe and late clipping. The damage to reproductive output was greater in the first year, when all defoliation treatments (even those clipped only once) were clipped late in the growing season, after plants were well into the reproductive phase and did not have enough time or resources for replacement spikes to mature (Noy-Meir and Briske 1996). In the second year, all treatments were clipped early in the vegetative phase, allowing plants clipped once or twice to recover before the reproductive stage. In addition, in the second year of the experiment, clipping height was not constant but was proportional to sward height. This is a more realistic simulation of grazing (Laca et al. 1992), which may have contributed to the less severe effects on reproduction. Over the two years of this experiment, and especially in the second year, both species managed to invest a reasonable fraction of the current season's biomass in the reproductive component. This was especially evident in the plants sampled under grazing conditions. In the case of $\mathrm{H}$. bulbosum, the substantial investment in corms ensures persistence into the following year under a wide range of cattle grazing intensities (Sternberg et al. 2000). In fact, the major danger to the persistence of $\mathrm{H}$. bulbosum in those grasslands is destruction by episodically exploding vole populations, particularly in ungrazed areas (NoyMeir 1988). In the case of T. dicoccoides, seed persistence in the soil is threatened by granivorous ants, and seedling establishment by competition with large numbers of equally well-adapted annual species.

The large investment of $\mathrm{T}$. dicoccoides in seeds ensures its annual regeneration under moderate grazing and, possibly, even under intense grazing in the vegetative phase. However, intense grazing into the reproductive phase can severely reduce the survival of wild wheat plants to maturity and seed production in the same year (Noy-Meir and Briske 1996). Because the life-span of T. dicoccoides seeds in the soil is only about two years (Horovitz 1998), repeated occurrences of intense grazing in the reproductive phase can reduce populations of wild wheat in intensely grazed rangeland to extinction or to very low density (Noy-Meir et al. 1989, Noy-Meir 2001). When first discovered at the beginning of the 20th century, T. dicoccoides was restricted to natural grazing refuges among rock outcrops or within spiny shrubs (Aaronsohn 1909). It was only after a sharp decrease in grazing intensity in Israel in the 1950s that its distribution expanded to less protected habitats (Zohary and Brick 1961, Harlan and Zohary 1966). 
In terms of the whole plant community, continuous and early grazing can greatly increase spatial

heterogeneity through gap formation, allowing the establishment and development of a more species-rich community (Sternberg et al. 2000). Moreover, late-season grazing during or shortly after plant reproduction can compromise the persistence of annual populations by reducing seed banks. This result has important implications for the conservation management of Mediterranean grasslands using cattle, because a diverse and spatially heterogeneous community could more easily achieve sustainability (Walker 1979, Tainton et al. 1996). Furthermore, it is important to recognize the indirect effects of grazing by modifying competitive interaction within the community. In some cases, indirect effects may be equally or more important in determining vegetation response to grazing than are direct grazing effects (Crawley 1983). In the case of the species studied, cattle showed no pattern in diet selection. The vertical defoliation imposed by cattle on tall grasses as a functional group was similar and had a greater effect on grassland heterogeneity than did cattle diet preferences. A diverse community also allows a widening of the seasonal forage flow, which in turn lengthens the grazing season (Seligman 1996), with consequent benefits for conservation and sustainable animal production in Mediterranean grasslands.

\section{RESPONSES TO THIS ARTI CLE}

Responses to this article are invited. If accepted for publication, your response will be hyperlinked to the article. To submit a comment, follow this link. To read comments already accepted, follow this link.

\section{Acknowledgments:}

The research was conducted at the Karei Deshe Experimental Range of the Israeli Ministry of Agriculture managed by Mr. Zadok Cohen. It was supported by grant 1705-89 from the US - Israel Binational Agricultural Research and Development (BARD) Fund.

\section{LITERATURE CITED}

Aaronsohn, A. 1909. Contribution à l'histoire des céréales: le blé, l'orge et le seigle à l'état sauvage. Bulletin du Société Botanique de France 56: 196-203, 237-245, 251-258.

Biswell, H. A., and J. E. Weaver. 1933. Effect of frequent clipping on the development of roots and tops of grasses in prairie sod. Ecology 14: 368-390.

Butler, J. L., and D. D. Briske. 1988. Population structure and tiller demography of the bunchgrass Schizachyrium scoparium in response to herbivory. Oikos 51: 306-312.

Caldwell, M. M., J. H. Richards, D. A. Johnson, R. S. Nowak, and R. S. Dzurec. 1981. Coping with herbivory: photosynthetic capacity and resource allocation in two semiarid Agropyron bunchgrasses. Oecologia 50: $14-24$.

Carman, J. G., and D. D. Briske. 1982. Root initiation and root and leaf elongation of dependent little bluestem tillers following defoliation. Agronomy J ournal 74: 432-435.

Crawley, M. J. 1983. Herbivory: the dynamics of plant-animal interactions. Blackwell Scientifc, Oxford, UK.

de Ridder, N., N. G. Seligman, and H. van Keulen. 1981. Analysis of environmental and species effects on 
Conservation Ecology: Biomass partitioning following defoliation of annual and perennial Mediterranean grasses

the magnitude of biomass investment in the reproductive effort of annual pasture plants. Oecologia 49: 253-271.

Deregibus, V. A., R. A. Sánchez, J. J. Casal, and M. J. Trlica. 1985. Tillering responses to enrichment of red light beneath the canopy in a humid natural grassland. Journal of Applied Ecology 22: 199-206.

Gutman, M., N. G. Seligman, and I. Noy-Meir. 1990. Herbage production of Mediterranean grassland under yearlong and seasonal grazing systems. J ournal of Range Management 43: 535-538.

Harlan, J. R., and Zohary, D. 1966. Distribution of wild wheats and barley. Science 153: 1074-1080.

Hill, M. J., and B. R. Watkin. 1975. Seed production studies on perennial ryegrass, timothy and prairie grass. 1. Effect of tiller age on tiller survival, ear emergence and seedhead components. Journal of the British Grassland Society 30: 63-71.

Horovitz, A. 1998. The soil seed bank of wild emmer. Pages 185-188 in Proceedings of the International Symposium on In Situ Conservation of Plant Genetic Diversity. CRIFC, I stanbul, Turkey.

Horvitz, C. C., and D. W. Schemske. 1988. Demographic cost of reproduction in a neotropical herb: an experimental field study. Ecology 69: 1741-1745.

Hunt, R., A. O. Nicholls, and S. A. Fathy. 1987. Growth and root-shoot partitioning in eighteen British grasses. Oikos 50: 53-59.

Johnson, I. R., and J. H. M. Thornley. 1987. A model of shoot: root partitioning with optimal growth. Annals of Botany 60: 133-142.

Kasperbauer, M. J., and D. L. Karlen. 1986. Light-mediated bioregulation of tillering and photosynthate partitioning in wheat. Physiologia Plantarum 66: 159-168.

Knight, R. 1970. The effects of plant density and frequency of cutting on the growth of cocksfoot (Dactylis glomerata L.). 1. The production of vegetative and reproductive tillers. Australian Journal of Agricultural Research 21: 9-17.

Koller, D., and H. R. Highkin. 1960. Environmental control of reproductive development in Hordeum bulbosum, a perennial grass. American J ournal of Botany 47: 843-847.

Laca, E. A., E. D. Ungar, N. G. Seligman, and M. W. Demment. 1992. Effects of sward height and bulk density on bite dimensions of cattle grazing homogeneous swards. Grass and Forage Science 47: 81-90.

Leopold, A. C. 1949. The control of tillering in grasses by auxin. American Jounral of Botany 36: 437-440.

Loehle, C. 1987. Partitioning of reproductive effort in clonal plants: a benefit- cost model. Oikos 49: 199-208.

Noy-Meir, I. 1978. Grazing and production in seasonal pastures. Journal of Applied Ecology 15: 809-935.

Noy-Meir, I. 1988. Dominant grasses replaced by ruderal forbs in a vole year in ungrazed Mediterranean grasslands. Journal of Biogeography 15: 579-587.

Noy-Meir, I. 2001. Ecology of wild emmer wheat in Mediterranean grassland in Galilee. Israel J ournal of Plant Protection Sciences 29, in press.

Noy Meir, I., and D. D. Briske. 1996. Fitness components of grazing induced population reduction in a dominant annual, Triticum dicoccoides (wild wheat). J ournal of Ecology 84: 439-448. 
Noy-Meir, I., M. Gutman, and Y. Kaplan. 1989. Responses of Mediterranean grassland plants to grazing and protection. Journal of Ecology 77: 290-310.

Ofir, M., D. Koller, and M. Negbi. 1967. Studies on the physiology of regeneration buds of Hordeum bulbosum. Botanical Gazette 128: 25-34.

Orshan, G. 1953. Note on the application of Raunkaier's system of life forms in arid regions. Palestine Journal of Botany 6: 120-122.

Parsons, A. J., and M. J. Robson. 1981. Seasonal changes in the physiology of S24 perennial ryegrass (Lolium perenne L.). 3. Partition of assimilates between root and shoot during the transition from vegetative to reproductive growth. Annals of Botany 48: 733-744.

Raunkaier, C. 1934. The life forms of plants and statistical plant geography. Clarendon, Oxford, UK.

Reekie, E. G., and F. A. Bazzaz. 1987. Reproductive effort in plants. 3. Effect of reproduction on vegetative activity. American Naturalist 129: 907-919.

Ryle, G. J. A. 1970. Partition of assimilates in an annual and perennial grass. Journal of Applied Ecology 7: 217-227.

SAS I nstitute. 1985. User's guide: statistics. Version 5. SAS Institute, Cary, North Carolina, USA.

Seligman, N. G. 1996. Management of Mediterranean grasslands. Page 359-391 in J. Hodgson and A. Illius, editors. The ecology and management of grazing systems. CAB International, Oxford, UK.

Spek, L., and M. van Oijen. 1988. A simulation model of root and shoot growth at different levels of nitrogen availability. Pages 115-121 in B. C. Loughman, O. Gasparikovà, and J. Kalek, editors. Structural and functional aspects of transport in roots. Kluwer Academic, Amsterdam, The Netherlands.

Sternberg, M., M. Gutman, A. Perevolotsky, E. D. Ungar, and J. Kigel. 2000. Vegetation response to grazing management in a Mediterranean herbaceous community: a functional group approach. Journal of Applied Ecology 37: 224-237.

Tainton, N. M., C. D. Morris, and M. B. Hardy. 1996. Complexity and stability in grazing systems. Pages 275299 in J. Hodgson and A. Illius, editors. The ecology and management of grazing systems. CAB International, Oxford, UK.

Walker, B. H. 1979. Management of semi-arid ecosystems. Elsevier, Amsterdam, The Netherlands.

Zohary, D., and Z. Brick. 1961. Triticum dicoccoides in Israel: notes on its distribution, ecology and natural hybridization. Wheat Information Service 13: 6-8.

Zohary, M. 1989. A new analytical flora of Israel. Am Oved, Tel Aviv, Israel.

\author{
Address of Correspondent: \\ Mario Gutman \\ Agricultural Research Organization \\ Department of Natural Resources \\ Volcani Center \\ P.O. Box 6 \\ Bet Dagan 50250 Israel \\ Phone: +972-6-6953511 \\ mgutman@shani.net
}


Home | Archives | About | Login | Submissions | Notify | Contact | Search 